Paper

\title{
Measurement of the negative ions temperature in the hydrogen sheet plasma using an omegatron mass spectrometer contained a function of an ion energy analyzer
}

\section{エネルギーフィルターを備えたオメガトロン型質量分析器による水素シートプラズマ中での負 イオン温度計測}

Toshikio TAKIMOTO, Takaaki IIJIMA, Yuta TANAKA, Akira TONEGAWA, Kazutaka KAWAMURA

Department of Physics, School of Science, Tokai University, 4-1-1 Kitakaname, Hiratsuka, Kanagawa, 259-1292, Japan

TEL: x81-463-58-1211(EX.3681) e-mail:2bsp1208@mail.ac.jp, atone@tsc.u-tokai.ac.jp

\section{Kohnosuke SATO}

Chubu Electric Power Co. Inc. 20-1, Kitasekiyama, Ohdaka-cyo, Midori-ku, Nagoya, Aichi, 459-8522, Japan

(Received 25 January, $2016 \quad$ Accepted 12 December, 2016)

\begin{abstract}
We succeeded in measuring the negative hydrogen ions temperature $T_{H^{-}}$in the sheet plasma by using an omegatron mass spectrometer. The $T_{H^{-}}$was determined by measuring the ion current as a function of the ion repeller voltage $V_{G 2}$ using the omegatron mass spectrometer. Calculated using an energy distribution function, $T_{H^{-}}$was approximately $0.27 \mathrm{eV}$ in the sheet plasma.
\end{abstract}

Keywords : Sheet plasma, Negative ion, Volume production, Omegatron mass spectrometer

\section{INTRODUCTION}

現在, 負イオンは磁場閉じ込め型核融合炉の中性粒子 ビーム入射加熱装置などのイオン源において重要な役 割を果たすと考えられている.これらの装置内において は磁場の影響があるため, 四重極子型質量分析器（Qmass）などの質量分析器による負イオンの粒子計測は困 難である. そのため, 通常ではレーザー光脱離法 1,2 に よる負イオン計測が主流となっている.しかし，このレ ーザー光脱離法は, 照射領域内の負イオンを破壊するこ とで生じる脱離電子電流ピークの緩和時間から負イオ

SAS Award was given to this paper presented as Poster Presentation at the 2015 SAS Symposium.
ンを計測しているため, 負イオン種を判別することは難 しい. これらの理由から, 我々は磁場中での測定が可能 なオメガトロン型質量分析器 3 を用いることを考えた. 本研究では, 負イオン源として東海大学の直線型シー トプラズマ生成装置 TPD-Sheet IV（Test Plasma produced by Direct current for Sheet plasma IV） 4-6 を用いた。本装 置では, 体積生成法を用いて水素負イオンを生成してい る. 体積生成では，まず高エネルギー電子 $\mathrm{e}(\mathrm{fast}) \quad\left(T_{e} \geq\right.$ $10-15 \mathrm{eV})$ の衝突によって水素分子が励起される（式 (1)). その後, 解離性電子付着の反応断面積が大きい振 動準位 6 以上の励起した水素分子 $\mathrm{H}_{2}{ }^{*}\left(v^{\prime \prime}>5\right)$ に, 低工 ネルギー電子 $\mathrm{e}($ slow $)\left(T_{e} \sim 1-2 \mathrm{eV}\right)$ が衝突することで, 水素負イオン $\mathrm{H}^{-}$が生成される (式(2))。4, 7-11 


$$
\begin{aligned}
& \mathrm{H}_{2}\left(X^{1} \Sigma_{g}{ }^{+}\right)+\mathrm{e}(\text { fast }) \rightarrow \mathrm{H}_{2}{ }^{*}\left(B^{1} \Sigma_{u}{ }^{+}, C^{1} \Pi_{u}\right)+\mathrm{e} \\
& \rightarrow \mathrm{H}_{2}{ }^{*}\left(X^{1} \Sigma_{g}{ }^{+}, v^{\prime \prime}\right)+\mathrm{h} v . \\
& \mathrm{H}_{2}{ }^{*}\left(X^{1} \Sigma_{g}{ }^{+}, v^{\prime \prime}\right)+\mathrm{e}(\text { slow }) \rightarrow \mathrm{H}^{-}+\mathrm{H} .
\end{aligned}
$$

ここから分かるように, 体積生成法では高エネルギー電 子と低エネルギー電子の領域が必要となる.また, 励起 した水素分子は短寿命であるため, 二つの領域は相応に 近接している必要がある. 本装置では, これら 2 つの条 件をシートプラズマの高温である中心領域 $\left(T_{e} \geq 10-\right.$ $12 \mathrm{eV})$ と低温である周辺領域 $\left(T_{e} \sim 1-2 \mathrm{eV}\right)$ において 達成している. ${ }^{4}$ そこで, 本研究では TPD-Sheet IV で生 成した水素プラズマ中における負イオン種の同定と負 イオン温度の計測を, オメガトロン型質量分析器により 行うことを目的とする.

\section{EXPERIMENTAL SETUPS}

本研究で用いた負イオン源である, 直線型シートプラ ズマ生成装置 TPD-Sheet IV の概念図を Fig. 1 に示す. TPD-Sheet IV で生成されるプラズマは, 放電領域と実験 領域の二領域に分けられる。水素シートプラズマは $\mathrm{LaB}_{6}$ 熱陰極とスリット（幅 $40 \mathrm{~mm} \times$ 高さ $2 \mathrm{~mm}$ ）を持つ 陽極間の直流放電により生成される.また, 11 個の長方 形の磁気コイルが $0.094 \mathrm{~T}$ で一定の磁場を実験領域に生 成することで, 実験領域まで生成されたプラズマを導く. シートプラズマは放電陽極から $Z$ 軸方向に $0.7 \mathrm{~m}$ 離れ た, 水冷され電気的に浮いたターゲットプレートで終端 する. プラズマは $0.05 \mathrm{~Pa}$ の放電チャンバー内において, 放電出力 $7.6 \sim 25 \mathrm{~kW}$ で生成される. 二次ガスはガスフ ィーダーから供給される.このガスフィーダーは実験領
域内の陽極から $0.6 \mathrm{~m}$ ，シートプラズマの下 $20 \mathrm{~mm}$ の位 置に設置されている. 二次水素ガスは低圧の実験領域内 の水素シートプラズマへ垂直に供給される. 実験領域内 の中性ガス圧力は, 二次水素ガス供給によって $0.1 \sim 2.3$ $\mathrm{Pa}$ の間で制御される。このとき, 放電領域へのコンダ クタンスが十分に小さいため, 実験領域内の中性ガス圧 力は放電領域内でのプラズマ生成には影響しない.

TPD-Sheet IV において, シートプラズマに二次ガスを 垂直に導入する利点として, (i)放電領域と実験（負イオ ン生成）領域が分けられているため, プラズマのパラメ ータや状態を二つの領域において自由に設定できるこ と (ii)放電をしながら放電電流とガス流量を自由に変化 させることで, プラズマ密度と電子温度に幅広い変化を 与えられること(iii)二次水素ガスを低温プラズマと高温 プラズマの両方が存在する狭い領域へ垂直に供給する ことで、シートプラズマが大きな温度勾配を持つプラズ マのような境界を持つことになる, 4 という点が挙げら れる. 先に述べたが，(iii)が負イオン生成におけるシー トプラズマの重要な特性であり, 過去の研究における電 子温度分布の計測から確認されている.

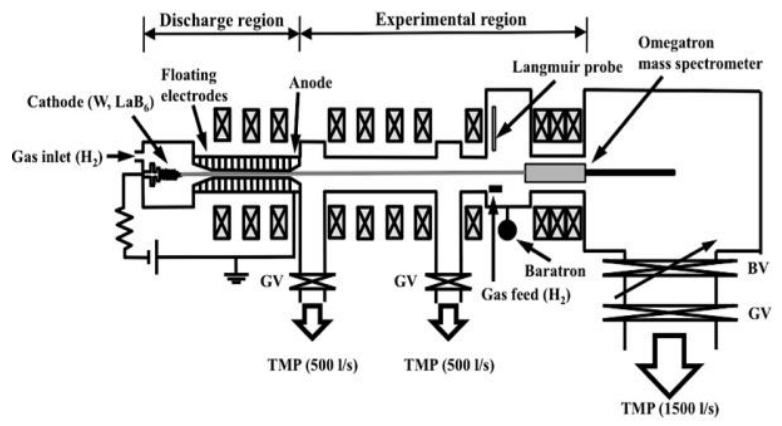

Fig. 1. Cross-sectional diagram of TPD-SheetIV.

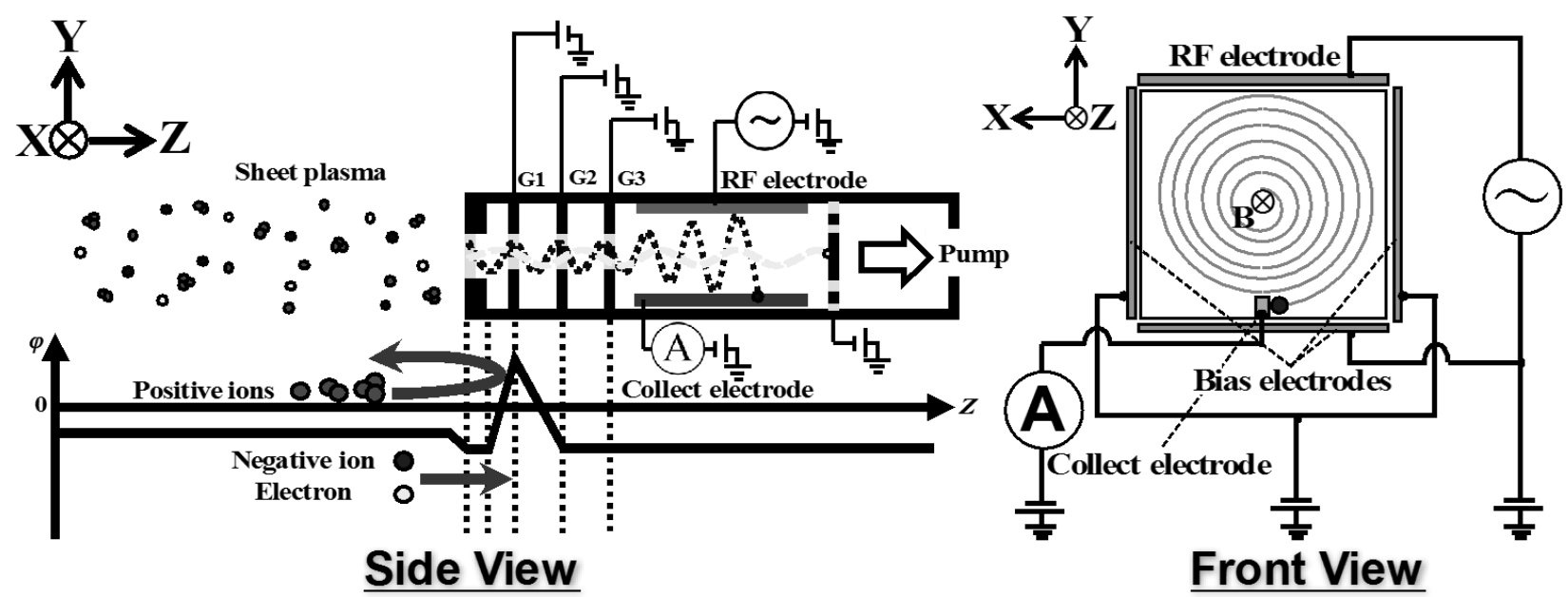

Fig. 2. Cross-sectional diagram of the omegatron mass spectrometer. 
負イオン計測に用いるオメガトロン型質量分析器の 概念図を Fig. 2 に示す. オメガトロン型質量分析器はピ ンホール（ $\phi=1.5 \mathrm{~mm} ）$ が開いたターゲットプレートの 後ろに設置され, 差動排気されている.オメガトロン質 量分析器は電気的に絶縁されており, プラズマ中に入れ るために全体を完全に覆った箱体のチャンバーとなっ ており, 水冷されている. 質量分析器の計測領域内部で は，第 1 グリッド（G1）で正の電圧を印加し正イオンの 追い返し，負イオンの引き込みが行われる，その後，第 2 グリッド（G2）および第 3 グリッド（G3）にプラズマ 中の浮遊電位と同等の電圧を印加し, 加速した負イオン の減速が行われる. 最後に, チャンバー内に引き込まれ た負イオンの Larmor 半径を，チャンバー上部の電極に 印加した高周波電場（Sine 波）により増大させ, 電子と 分離し, チャンバー下部に設置されたコレクタ電極で捕 集する.このとき，高周波を掃引することで，イオンサ イクロトロン周波数 $f_{C}=\mathrm{e} B / 2 \pi m$ と高周波電場の周波 数が等しいときのみ, 検出される電流值にピークが現れ る. また, オメガトロン型質量分析器で負イオン温度を 計測する場合は, 第 2 グリッドの印加電圧 $V_{G 2}$ を変化さ せることで，第 1 グリッドで引き込んだ負イオンのう ち, 印加電圧以下のエネルギーしか持たない負イオンを 選択的に排除する.これによってコレクタ電極で検出さ れる負イオン電流ピーク $I_{H^{-}}$の変化が生じるため, 第 2 グリッドの印加電圧との相関（V-I 特性）を得ることが できる.

\section{RESULT AND DISCUSSION}

放電電力 $13 \mathrm{~kW}$ における，コレクタ電流 $I_{C}$ と高周波 電極への印加周波数との相関を Fig. 3 に示す. 負イオン



Fig. 3. The negative hydrogen ions mass spectrum by measuring the omegatron mass spectrometer.
を計測する際は, 実験領域内の中性ガス圧力 $P=0.3 \mathrm{~Pa}$, プラズマ中心から垂直方向に $Y=12 \mathrm{~mm}$, グリッド電圧 $V_{G 2}=5 \mathrm{~V}$ に設定した。 また，計測領域の磁場強度は $B=$ $0.08 \mathrm{~T}$ で，このときの水素負イオン $\mathrm{H}^{-}$のサイクロトロ ン周波数は $f_{C}=1.2 \mathrm{MHz}$ であり, Fig. 3 の電流ピークの 位置とよく一致している. したがって, シートプラズマ 中における $\mathrm{H}^{-}$のイオン種分析を行うことができたと考 えられる。

オメガトロン型質量分析器で得られた, 第 2 グリッド の印加電圧 $V_{G 2}$ に対する負イオン電流ピーク $I_{H^{-}}$の変化 と, その微分曲線 $d I_{H^{-}} / d V_{G 2}$ を Fig. 4 に示寸. 実験条件 は, 放電電力が $13 \mathrm{~kW}, P=0.3 \mathrm{~Pa}, Y=12 \mathrm{~mm}$ と質量分 析の場合と同じである. 実験から得られた V-I 特性から 水素負イオンの平行方向の速度分布関数を求めること で, 水素負イオン温度 $T_{H^{-}}$を以下の式のように求めるこ とができる. 12

$$
T_{H^{-}} \approx\left\langle\frac{\left(m_{H^{-}}\right) v_{\|}^{2}}{2 e}\right\rangle=\frac{\int_{-\infty}^{\infty} \frac{\left(m_{H^{-}}\right) v_{\|}^{2}}{2 e} f\left(v_{\|}\right) d v_{\|}}{\int_{-\infty}^{\infty} f\left(v_{\|}\right) d v_{\|}}
$$

ここで, $v_{\|}$は負イオンの平行速度成分, $m_{H^{-}}$は水素負イ オンの質量である。(3)式より，水素負イオン温度 $T_{H}$-は $0.27 \mathrm{eV}$ と求まった。ここで，負イオンの体積生成にお ける水素分子の解離エネルギー $13(<2 \mathrm{eV})$ と比較する と, 得られた水素負イオン温度 $T_{H^{-}}$は十分に小さいため, 妥当な数值であると判断できる.

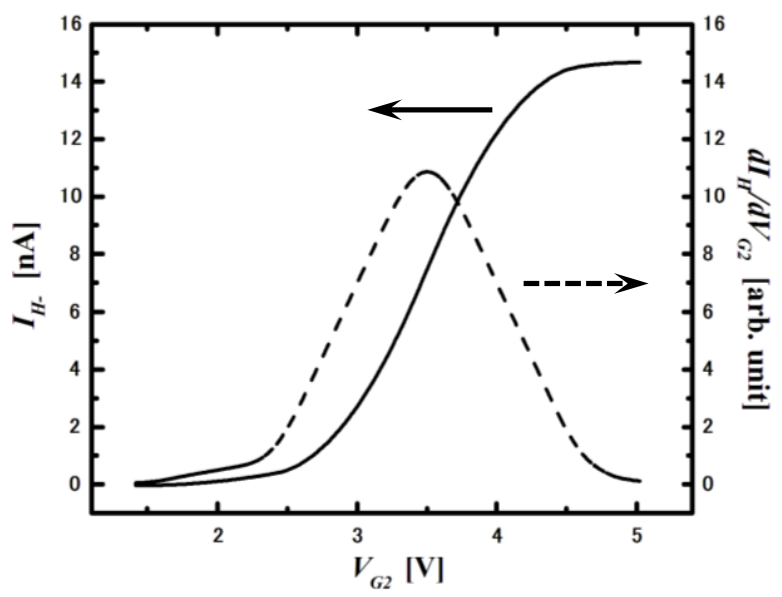

Fig. 4. Characteristics of $V_{G 2}-I_{H^{-}}$and $d I_{H^{-}} / d V_{G 2}$ curve as a function of repeller bias voltage $V_{G 2}$ by measuring the omegatron mass spectrometer.

\section{SUMMARY AND FUTURE PLAN}

本研究では, オメガトロン型質量分析器により直線型 ダイバータ模擬装置 TPD-Sheet IV で生成した水素シー 
トプラズマ中の負イオン種および負イオン温度の計測 を目的とした。実験では, 水素負イオン $\mathrm{H}$ の特定に成 功し, 水素負イオン温度 $T_{H^{-}}$を $0.27 \mathrm{eV}$ と求めることが できた。

マルチグリッド式イオンエネルギーアナライザーの イオン温度計測においては, グリッドメッシュの細かさ がエネルギー分解能に影響するという報告 14 があるが, 我々の計測装置では電流の検出にイオンサイクロトロ ン加熱を用いているため, これらの機構が相互に影響し 合っていると予想される. したがって, イオンサイクロ トロン加熱がイオン温度計測に及ぼす影響を明らかに していくことが今後の課題であると考える.

\section{REFERENCES}

1 M. Bacal, G. W. Hamilton, A. M. Bruneteau, H. J. Doucet and J. Taillet: Rev. Sci. Instrum., 50, 719 (1979).

2 P. Devynck, J. Auvray, M. Bacal, P. Berlemont, J. Bruneteau, R. Leroy and R. A. Stern: Rev. Sci. Instrum., 60, 2873 (1989).

3 E. M. Hollmann, G. Antar, R. P. Doerner and S. C. Luckhardt: Rev. Sci. Instrum., 72, 623 (2001).

4 A. Tonegawa, K. Kumita, M. Ono, T. Shibuya and K. Kawamura: Jpn. J. Appl. Phys., 45, 8212 (2006).
5 H. Yazawa, A. Tonegawa, M. Ono, T. Shibuya and K. Kawamura: Jpn. J. Appl. Phys., 45, 8208 (2006).

6 T. Iijima, S. Hagiwara, S. Tanaka, A. Tonegawa, K. Kawamura and K. Sato: Fusion Science and Technology, 63, 417 (2013).

7 W. G. Graham: J. Phys., D 17, 2225 (1984).

8 R. I. Hall, I. Čadež, M. Landau, F. Pichou, and C. Schermann: Phys. Rev. Lett., 60, 337 (1988).

9 C. Schermann, F. Pichou, M. Landau, I. Čadež and R. I. Hall: J. Chem. Phys., 101, 8152 (1994).

${ }^{10}$ O. Fukumasa, N. Mizuki and E. Niitani: Rev. Sci. Instrum., 69, 995 (1998).

${ }^{11}$ O. Fukumasa, S. Mori, N. Nakada, Y. Tauchi, M. Hamabe, K. Tsumori and Y. Takeiri: Contrib. Plasma Phys., 44, 516 (2004).

${ }^{12}$ A. Matsubara, A. Tonegawa, T. Shibuya, K. Sato, K. Kawamura and K. Takayama: J. Appl. Phys., 89, 5326 (2001).

${ }^{13}$ R. Celiberto, R.K. Janev, A. Laricchiuta, M. Capitelli, J.M. Wadehra, D.E. Atems: Atomic Data and Nuclear Data Tables, 77, 161-213 (2001).

${ }^{14}$ H. Ikezi and R. J. Taylor: J. Appl. Phys., 41, 738 (1970). 